\title{
KAJIAN SIFAT FISIK, KIMIA DAN SENSORIS CRACKERS SUBSTITUSI TEPUNG SUKUN (Artocarpus communis) TERMODIFIKASI ASAM ASETAT DENGAN PENAMBAHAN SARI DAUN PANDAN WANGI (Pandanus amaryllifolius)
}

\author{
THE STUDY OF PHYSIC, CHEMICAL AND SENSORY CHARACTERISTIC OF CRACKERS \\ SUBSTITUTED BY ACETIC ACID MODIFIED BREADFRUIT FLOUR (Artocarpus \\ communis) WITH ADDITION OF EXTRACT PANDAN LEAVES (Pandanus amaryllifolius)
}

\section{Dwi Astuti, Kawiji, Edhi Nurhartadi}

\author{
Program Studi Teknologi Pangan, Fakultas Pertanian, UNS Surakarta \\ J1. Ir. Sutami 36A Kentingan, Jebres, Surakarta, Indonesia 57126 \\ email: dwiastutiitp12@gmail.com
}

Diserahkan [9 Oktober 2017]; Diterima [10 Desember 2017]; Dipublikasi [26 Februari 2018]

\begin{abstract}
The purpose of this research was to determine the effect of substitution of acetic acid modified breadfruit flour with the addition of pandan leaves extract against physic, chemical and sensory characteristic of crackers and determine their antioxidant activity on crackers. This study uses a Completely Randomized Design (CRD) with one factor substitution of acetic acid modified breadfruit flour. Sensory data were analyzed by one-way ANOVA, if there is a difference it was followed with significance test using Duncan's Multiple Range Test (DMRT) at significance level of 0,05. The results showed that substitution of acetic acid modified breadfruit flour did not significantly affect the physical characteristic (hardness), chemical characteristics such as moisture content, ash, protein, carbohydrate and antioxidant activity of crackers. However, the substitution of acetic acid modified breadfruit flour affected the levels of fat, crude fiber, sensory characteristics (colour, flavor, taste, texture and overall) of crackers. The antioxidant activity of crackers is about 3.27\%-4.16\%.
\end{abstract}

Keywords: acetic acid modification, breadfruit, crackers, extract pandan leaves

\section{ABSTRAK}

Tujuan penelitian ini adalah untuk mengetahui pengaruh substitusi tepung sukun termodifikasi asam asetat dengan penambahan sari daun pandan wangi terhadap karakteristik fisik, kimia dan sensoris crackers serta mengetahui adanya aktivitas antioksidan pada crackers. Penelitian ini menggunakan Rancangan Acak Lengkap (RAL) dengan satu faktor yaitu substitusi tepung sukun termodifikasi asam asetat. Data sensoris dianalisis dengan one way ANOVA, jika terdapat perbedaan maka dilanjutkan dengan uji beda nyata menggunakan analisis Duncan's Multiple Range Test (DMRT) pada taraf signifikansi $\alpha=0,05$. Hasil penelitian menunjukkan bahwa substitusi tepung sukun termodifikasi asam asetat tidak berpengaruh nyata terhadap karakteristik fisik (kekerasan), karakteristik kimia seperti kadar air, abu, protein, karbohidrat dan aktivitas antioksidan crackers. Namun substitusi tepung sukun termodifikasi asam asetat ini memiliki pengaruh yang nyata terhadap kadar lemak, serat kasar dan karakteristik sensori (warna, aroma, rasa, tekstur dan overall) crackers. Crackers yang dihasilkan memiliki aktivitas antioksidan sebesar 3,27\%-4,16\%.

Kata kunci: modifikasi asam asetat, sukun, crackers, sari daun pandan wangi

\section{PENDAHULUAN}

Tanaman sukun (Artocarpus communis) merupakan tanaman tahunan yang termasuk dalam famili Moraceae yang berasal dari daerah Pasifik, Polinesia dan Asia Tenggara, termasuk Indonesia. Di Indonesia, tanaman sukun tersebar luas mulai dari provinsi Aceh sampai Papua. Menurut data Badan Pusat Statistik (2015), produksi sukun di Indonesia pun cukup tinggi terbukti pada tahun 2014 produksinya mencapai 103.491 ton dimana Jawa Tengah merupakan daerah penghasil buah sukun tertinggi sebesar 21.444 ton.

Buah sukun mengandung karbohidrat $35,5 \%$, protein $0,1 \%$, lemak $0,2 \%$, abu $1,21 \%$, fosfor $0,048 \%$, kalsium $0,21 \%$, besi $0,0026 \%$, air $61,8 \%$ dan serat $2 \%$ (Waryat dkk., 2014). Namun, pemanfaatan buah ini biasanya hanya dijadikan makanan ringan dengan cara direbus, digoreng atau dibuat keripik. Buah sukun merupakan golongan buah klimaterik yang pola respirasinya terjadi secara cepat sehingga mudah busuk dengan umur simpan yang relatif singkat 3-4 
hari (Purba, 2002). Buah sukun perlu diolah menjadi tepung untuk meningkatkan pemanfaatan dan umur simpannya. Tepung sukun mempunyai prospek yang baik untuk mengurangi penggunaan tepung terigu sebagai bahan baku dalam pembuatan produk bakery seperti bolu, cake, brownies, roti, fresh role cake, kue lapis, cookies, crackers dan lain-lain (Sitohang dkk., 2015).

Salah satu produk bakery yang banyak dijumpai hampir di semua toko di perkotaan dan pelosok desa adalah crackers. Crackers dibuat dari adonan melalui proses fermentasi, berbentuk pipih yang rasanya lebih mengarah ke asin dan renyah serta bila dipatahkan penampang potongan berlapis. Menurut Sugiyono dkk. (2013), ciri utama crackers berupa tekstur yang renyah, tidak padat dan tidak keras bila digigit. Crackers biasanya terbuat dari tepung terigu, lemak, garam dan agen fermentasi seperti ragi, gula dan ditambahkan air (Manoppo, 2012). Penggunaan terigu dalam pembuatan crackers dapat disubstitusi dengan tepung sukun untuk mengurangi masalah ketergantungan dan impor tepung terigu.

Namun pada penelitian Astuti dkk. (2013) menunjukkan peningkatan nilai kekerasan non-flaky crackers seiring dengan penambahan tepung sukun yang semakin banyak. Tepung sukun memiliki karakteristik yang kurang dikehendaki yaitu kurang dapat mengembang dan sedikit mengikat air sehingga perlu dilakukan modifikasi untuk memperbaiki karakteristik tersebut. Salah satu metode modifikasi dengan biaya murah, waktu singkat dan metode yang mudah adalah modifikasi secara kimia dengan penambahan reagen tertentu untuk mengganti gugus hidroksil $\left(\mathrm{OH}^{-}\right)$pada pati.

Penelitian yang dilakukan oleh Mutmainah dkk. (2013) menggunakan reagen asam asetat pada modifikasi asetilasi tepung sukun menunjukkan peningkatan viskositas, derajat putih, swelling power, kadar air dan gula reduksi dari tepung seiring dengan bertambahnya konsentrasi asam asetat dan lamanya perendaman. Sedangkan penelitian Hartanti dkk. (2013) menggunakan asam laktat pada modifikasi tepung sukun menunjukkan penurunan kadar gula reduksi, swelling power, viskositas dan peningkatan derajat putih seiring dengan bertambahnya konsentrasi asam laktat dan menunjukkan penurunan gula reduksi dan peningkatan derajat putih seiring dengan lamanya waktu perendaman. Dari kedua penelitian tersebut diketahui bahwa penggunaan asam asetat lebih menguntungkan dibandingkan asam laktat.

Penelitian yang telah dilakukan Mutmainah dkk. (2013) dengan perlakuan perbedaan konsentrasi asam asetat $(0 \%$, $0,05 \%, 0,1 \%, 0,15 \%$ ) dan lama perendaman (30, 60, 90 menit) menunjukkan peningkatan swelling power dan derajat putih tepung sukun. Swelling power merupakan kekuatan tepung untuk mengembang. Reaksi asetilasi akan melemahkan ikatan hidrogen di antara pati sehingga struktur granula pati menjadi kurang rapat dan mudah menyerap air. Nilai swelling power tertinggi didapatkan pada perlakuan konsentrasi asam asetat $0,15 \%$ dengan lama perendaman selama 90 menit.

Seiring perkembangan zaman, perlu inovasi pengolahan crackers untuk lebih menarik minat konsumen dan memberikan nilai tambah pada crackers. Salah satu cara yang dapat dilakukan adalah memanfaatkan kelimpahan jumlah dan spesies pandan di Indonesia. Pandan dapat digunakan sebagai bahan penyedap, pewangi dan pemberi warna hijau pada masakan (Marina dan Astuti, 2012). Selain itu daun pandan mengandung senyawa fenolik sebagai antioksidan yang dapat menangkal radikal bebas.

Substitusi tepung sukun termodifikasi asam asetat dengan penambahan sari daun pandan wangi diduga akan berpengaruh terhadap karakteristik fisik, kimia dan sensoris crackers serta dapat memberikan aktivitas antioksidan pada crackers. Oleh karena itu, perlu dilakukan penelitian untuk mengetahui karakteristik fisik, kimia, sensoris dan adanya aktivitas antioksidan pada crackers.

\section{METODE PENELITIAN}

\section{Bahan}

Sampel yang digunakan dalam pembuatan tepung termodifikasi adalah buah sukun yang diperoleh dari Pasar Legi, Surakarta, asam asetat, aquades. Dalam pembuatan crackers juga diperlukan bahan 
tambahan seperti tepung terigu, ragi, baking soda, gula halus, margarin, garam, susu skim, air dan sari daun pandan wangi. Sedangkan bahan untuk analisis antara lain pelarut benzene, $\mathrm{H}_{2} \mathrm{SO}_{4}$ pekat, $\mathrm{NaOH}$, $\mathrm{K}_{2} \mathrm{SO}_{4}$, alkohol 95\%, methanol dan DPPH $0,3 \mathrm{mM}$.

Alat

Alat yang digunakan yaitu pisau, baskom, gelas beaker (Pyrex) $500 \mathrm{ml}$, waterbath (Memmert), cabinet dryer, ayakan ukuran 80 mesh, neraca analitik (Acis), spatula, rolling pin, oven (Hitachi), texture analyzer LFRA 4500, botol timbang, desikator (Pyrex), oven (Memmert), tanur (Neycraft), labu Kjeldhal, destruktor dan labu destilasi, hot plate (Heidolph), alat ekstraksi soxhlet, oven (Memmert), neraca analitik (Adventurer), alat ekstraksi soxhlet, spektrofotometer (Shimadzu), vortex (Heidolph). Sedangkan alat yang digunakan untuk analisis sifat sensoris yaitu borang, nampan, piring kecil.

\section{Tahapan Penelitian}

\section{Pembuatan Tepung Sukun Termodifikasi}

Buah sukun dibelah dan dikupas kulitnya dan dipisahkan dari empulurnya. Daging buah selanjutnya direndam dalam air bersih dan dilanjutkan proses pengecilan ukuran dengan ketebalan 1-2 mm menggunakan pisau. Setelah pengecilan ukuran, dilakukan perendaman dalam asam asetat dengan konsentrasi sebesar 0,15\% (v/v) hingga $375 \mathrm{ml}$ larutan kemudian dipanaskan dalam water bath dengan suhu $45^{\circ} \mathrm{C}$ dengan lama perendaman selama 90 menit. Setelah proses perendaman, daging buah sukun ditiriskan dan dikeringkan dalam cabinet dryer pada suhu $60^{\circ} \mathrm{C}$ selama 6 jam. Daging buah sukun yang sudah kering selanjutnya ditepungkan dan diayak dengan ayakan ukuran 80 mesh.

\section{Pembuatan Sari Daun Pandan Wangi}

Proses pembuatan sari daun pandan wangi dimulai dengan pencucian daun pandan sampai bersih kemudian dilakukan pengecilan ukuran dengan pemotongan. Selanjutnya proses penghancuran menggunakan blender dengan penambahan air dan dilakukan penyaringan untuk mendapatkan sari daun pandan wangi.

Tabel 1 Perbandingan Tepung Terigu dan Tepung Sukun Termodifikasi

\begin{tabular}{ccc}
\hline Formula & $\begin{array}{c}\text { Tepung } \\
\text { terigu }(\%)\end{array}$ & $\begin{array}{c}\text { Tepung sukun } \\
\text { modifikasi }(\%)\end{array}$ \\
\hline 1 & 100 & 0 \\
2 & 90 & 10 \\
3 & 80 & 20 \\
4 & 70 & 30 \\
\hline
\end{tabular}

\section{Pembuatan Crackers}

Proses pertama diawali dengan pencampuran margarin, garam, susu dan gula yang dilanjutkan pengadukan selama 10 menit. Kemudian pencampuran dengan terigu, tepung sukun termodifikasi, ragi serta air sesuai formula yang dapat dilihat pada Tabel 1. Adonan diaduk sampai kalis dan kemudian difermentasi selama 30 menit. Setelah itu pemipihan adonan menjadi lembaran menggunakan rolling pin dan laminasi dengan penambahan bahan pengisi (tepung terigu, baking soda) di antara lembaran adonan. Adonan dicetak dengan ukuran yang seragam dan difermentasi kembali selama 10 menit. Setelah itu proses pemanggangan pada oven suhu $160^{\circ} \mathrm{C}$ selama 15 menit.

Analisis sampel dilakukan pada pengujian tekstur dengan diukur atribut kekerasan dengan menggunakan alat Texture Analyzer LFRA4500, pengujian kadar air dengan metode Thermogravimetri (AOAC, 2002), kadar abu dengan cara kering (AOAC, 2002), kadar lemak dengan metode ekstraksi Soxhlet (AOAC, 2002), kadar protein dengan metode Kjeldahl (AOAC, 2002), kadar karbohidrat dengan metode by difference (Winarno, 2008), kadar serat kasar dengan metode asam basa (Sudarmadji dkk., 1989), aktivitas antioksidan dengan metode DPPH (Subagio dan Morita, 2001) dan analisis sensoris dengan metode uji kesukaan (Setyaningsih dkk., 2010).

\section{Rancangan Penelitian}

Rancangan percobaan yang digunakan dalam penelitian ini adalah Rancangan Acak Lengkap (RAL) dengan satu faktor yaitu variasi komposisi tepung sukun termodifikasi dan tepung terigu sebagai bahan dasar pembuatan crackers. 
Percobaan dilakukan menggunakan satu sampel dengan tiga kali ulangan. Data yang diperoleh kemudian dianalisis menggunakan metode One Way ANOVA. Jika terdapat beda nyata, dilanjutkan dengan uji beda nyata menggunakan Duncan Multiple Range Test (DMRT) pada taraf signifikansi $\alpha=$ 0,05 .

\section{HASIL DAN PEMBAHASAN}

\section{Karakteristik Fisik dan Kimia Crackers}

Pengujian karakteristik fisik dan kimia crackers meliputi kekerasan, kadar air, abu, lemak, protein, karbohidrat, serat kasar dan aktivitas antioksidan. Hasil pengujian karakteristik fisik dan kimia crackers dapat dilihat pada Tabel 2.

\section{Kekerasan}

Tekstur merupakan sesuatu yang penting dalam menilai mutu makanan. Pada produk makanan seperti crackers umumnya memiliki tekstur renyah dan bila dipotong penampang potongannya berlapis-lapis (Manoppo, 2012). Salah satu ciri tekstur yang sering diacu adalah kekerasan. Prinsip dari pengukuran kekerasan yaitu besarnya gaya yang diperlukan untuk memecahkan produk (Sugiyono dkk., 2013).

Berdasarkan Tabel 2 dapat diketahui bahwa substitusi tepung sukun termodifikasi asam asetat $0 \%$ (kontrol), 10\%, 20\% dan
$30 \%$ menunjukkan tingkat kekerasan yang tidak berbeda nyata secara signifikan pada taraf signifikansi $\alpha=0,05$. Tingkat kekerasan crackers substitusi tepung sukun termodifikasi asam asetat 0\%-30\% memiliki range nilai kekerasan sebesar 15,77-19,47 N. Penelitian yang dilakukan Mutmainah dkk. (2013) menunjukkan swelling power tepung sukun termodifikasi asam asetat sebesar $5,21 \mathrm{~g} / \mathrm{g}$ dan swelling power tepung terigu menurut Sabirin dkk. (2012) sebesar 5g/g. Swelling power merupakan kekuatan tepung untuk mengembang. Nilai swelling power kedua jenis tepung ini tidak terlalu berbeda jauh. Pada tepung sukun termodifikasi asam asetat, gugus asetil dari asam asetat menggantikan gugus $\mathrm{OH}^{-}$pada pati. Substitusi gugus asetil ini melemahkan ikatan hidrogen pada pati sehingga air menjadi lebih mudah berpenetrasi ke dalam granula pati (Mutmainah dkk., 2013).

\section{Kadar Air}

Air merupakan komponen penting dalam bahan pangan karena air dapat mempengaruhi penampakan, tekstur serta cita rasa makanan (Winarno, 2008). Kadar air merupakan parameter penting untuk mengetahui mutu suatu produk dimana semakin rendah kadar air maka semakin baik mutunya (Mutmainah dkk., 2013).

Tabel 2 Karakteristik Fisik dan Kimia Crackers Substitusi Tepung Sukun Termodifikasi Asam Asetat dengan Penambahan Sari Daun Pandan Wangi

\begin{tabular}{lllll}
\hline \multicolumn{1}{c}{ Parameter } & \multicolumn{4}{c}{ Formula } \\
\cline { 2 - 5 } & \multicolumn{1}{c}{ F1 } & \multicolumn{1}{c}{ F2 } & F3 & F4 \\
\hline Kekerasan (N) & $16,26 \pm 3,97^{\mathrm{a}}$ & $15,77 \pm 2,29^{\mathrm{a}}$ & $19,47 \pm 4,44^{\mathrm{a}}$ & $19,33 \pm 6,33^{\mathrm{a}}$ \\
Kadar air (\%wb) & $4,01 \pm 0,76^{\mathrm{a}}$ & $3,97 \pm 0,85^{\mathrm{a}}$ & $3,77 \pm 0,86^{\mathrm{a}}$ & $2,92 \pm 0,51^{\mathrm{a}}$ \\
Kadar abu (\%wb) & $2,64 \pm 0,31^{\mathrm{a}}$ & $2,68 \pm 0,44^{\mathrm{a}}$ & $2,87 \pm 0,40^{\mathrm{a}}$ & $2,94 \pm 0,37^{\mathrm{a}}$ \\
Kadar lemak (\%wb) & $9,80 \pm 0,09^{\mathrm{b}}$ & $9,65 \pm 0,16^{\mathrm{b}}$ & $9,37 \pm 0,21^{\mathrm{a}}$ & $9,28 \pm 0,31^{\mathrm{a}}$ \\
Kadar protein (\%wb) & $10,57 \pm 1,61^{\mathrm{a}}$ & $9,85 \pm 0,71^{\mathrm{a}}$ & $9,64 \pm 1,06^{\mathrm{a}}$ & $9,25 \pm 1,16^{\mathrm{a}}$ \\
Kadar karbohidrat (\%wb) & $73,49 \pm 2,49^{\mathrm{a}}$ & $74,17 \pm 2,20^{\mathrm{a}}$ & $74,46 \pm 2,33^{\mathrm{a}}$ & $75,61 \pm 2,21^{\mathrm{a}}$ \\
Serat kasar (\%) & $1,04 \pm 0,18^{\mathrm{a}}$ & $1,57 \pm 0,27^{\mathrm{b}}$ & $2,06 \pm 0,26^{\mathrm{c}}$ & $2,61 \pm 0,23^{\mathrm{d}}$ \\
Aktivitas antioksidan (\%) & $3,41 \pm 0,42^{\mathrm{a}}$ & $3,87 \pm 0,76^{\mathrm{a}}$ & $3,27 \pm 0,62^{\mathrm{a}}$ & $4,16 \pm 0,76^{\mathrm{a}}$ \\
\hline
\end{tabular}

Keterangan:

1. Formula: F1 (0\% tepung sukun termodifikasi sebagai kontrol), F2 (10\% tepung sukun termodifikasi), F3 (20\% tepung sukun termodifikasi), F4 (30\% tepung sukun termodifikasi).

2. Notasi huruf yang berbeda pada baris yang sama menunjukkan beda nyata pada taraf signifikansi $\alpha=0,05$ 
Berdasarkan Tabel 2 dapat diketahui bahwa substitusi tepung sukun termodifikasi asam asetat sebesar 0-30\% menunjukkan kadar air yang tidak berbeda nyata secara signifikan pada taraf signifikansi $\alpha=0,05$. Kadar air tepung sukun termodifikasi asam asetat menurut Mutmainah dkk. (2013) sebesar $10,18 \%$ sedangkan kadar air tepung terigu menurut Sabirin dkk. (2012) sebesar $11,1 \%$. Nilai kadar air pada kedua jenis tepung ini tidak berbeda terlalu jauh sehingga produk yang dihasilkan memiliki kadar air yang tidak berbeda jauh pula. Menurut SNI. 01-2973-1992 diketahui bahwa kadar air crackers maksimal 5\%. Kadar air crackers substitusi tepung sukun termodifikasi asam asetat sebesar $0-30 \%$ memiliki range nilai 2,92-4,01\%. Kadar air yang dihasilkan semua formula masih memenuhi standar SNI.

\section{Kadar Abu}

Kadar abu berhubungan dengan kandungan mineral dalam suatu bahan pangan. Pada proses pembakaran, bahanbahan organik terbakar tetapi zat anorganiknya tidak yang dikenal sebagai abu (Winarno, 2008).

Berdasarkan Tabel 2 dapat diketahui bahwa substitusi tepung sukun termodifikasi asam asetat sebesar 0-30\% menunjukkan kadar abu yang tidak berbeda nyata secara signifikan pada taraf signifikansi $\alpha=0,05$. Kadar abu crackers substitusi tepung sukun termodifikasi asam asetat sebesar 0-30\% memiliki range nilai sebesar 2,64-2,94\%. Menurut SNI. 01-2973-1992 diketahui bahwa kadar abu crackers maksimal $2 \%$. Kadar abu yang dihasilkan semua formula memiliki nilai yang melebihi standar yang ditentukan SNI. Menurut Sudarmadji dkk. (1989), kandungan abu serta komposisinya tergantung pada jenis bahan pangan dan cara pengabuannya. Pada proses pengabuan dimungkinkan terjadi oksidasi zat organik yang kurang sempurna sehingga kadar abu melebihi standar SNI.

\section{Kadar Lemak}

Lemak merupakan polimer yang tersusun dari unsur karbon, hidrogen dan oksigen. Lemak mempunyai sifat yang tidak larut air (Winata, 2001). Penggunaan lemak pada produk bakery bertujuan untuk memperbaiki tekstur dan cita rasa bahan pangan (Winarno, 2008).

Berdasarkan Tabel 2 dapat diketahui bahwa substitusi tepung sukun termodifikasi asam asetat sebesar 0-30\% menunjukkan kadar lemak yang berbeda nyata secara signifikan pada taraf signifikansi $\alpha=0,05$. Semakin banyak jumlah substitusi tepung sukun termodifikasi asam asetat menghasilkan kadar lemak yang semakin rendah. Hal ini sesuai dengan penelitian Astuti dkk. (2013) yang menunjukkan semakin tinggi substitusi tepung sukun dalam pembuatan non flaky crackers maka kadar lemak menjadi semakin rendah. Penelitian oleh Sitohang dkk., 2015 juga menunjukkan semakin tinggi penggunaan tepung sukun maka kadar lemak akan mengalami penurunan pada produk cookies. Penurunan kadar lemak disebabkan karena kadar lemak pada tepung terigu yang lebih tinggi dibandingkan dengan kadar lemak pada tepung sukun. Kadar lemak yang terdapat pada tepung terigu sebesar $0,98 \%$ sedangkan kadar lemak pada tepung sukun sebesar 0,24\% (Sitohang dkk., 2015). Pada tepung sukun yang termodifikasi asam asetat dimungkinkan terjadi penurunan kadar lemak. Hal ini didukung oleh penelitian Gonzalez and Perez (2002) yang menunjukkan penurunan kadar lemak pada pati beras terasetilasi sebesar $1,18 \%$ dari kadar lemak pati beras alami.

\section{Kadar Protein}

Protein merupakan suatu zat makanan yang penting bagi tubuh sebagai zat pembangun dan pengatur proses dalam tubuh. Protein adalah sumber asam amino yang mengandung unsur $\mathrm{C}, \mathrm{H}, \mathrm{O}$ dan $\mathrm{N}$ yang tidak dimiliki oleh lemak ataupun karbohidrat (Winarno, 2008).

Berdasarkan Tabel 2 dapat diketahui bahwa substitusi tepung sukun termodifikasi asam asetat sebesar 0-30\% menunjukkan kadar protein yang tidak berbeda nyata. Menurut SNI. 01-2973-1992 diketahui bahwa kadar protein crackers minimal $8 \%$. Kadar protein crackers substitusi tepung sukun termodifikasi asam asetat sebesar 0$30 \%$ memiliki range nilai sebesar 9,25$10,57 \%$. Kadar protein yang dihasilkan 
semua formula masih memenuhi standar yang ditetapkan SNI.

\section{Kadar Karbohidrat}

Karbohidrat merupakan sumber kalori utama pada hampir seluruh penduduk dunia. Karbohidrat juga memiliki peranan penting dalam menentukan karakteristik bahan pangan seperti rasa, warna, tekstur dan lainlain. Penentuan kadar karbohidrat dilakukan menggunakan Carbohydrate by Difference (Winarno, 2008).

Berdasarkan Tabel 2 dapat diketahui bahwa substitusi tepung sukun termodifikasi asam asetat sebesar 0-30\% menunjukkan kadar karbohidrat yang tidak berbeda nyata secara signifikan pada taraf sigifikansi $\alpha=$ 0,05. Kadar karbohidrat crackers substitusi tepung sukun termodifikasi asam asetat sebesar 0-30\% memiliki range nilai sebesar 73,49-75,61\%. Menurut Sugito dan Hayati (2006), kadar karbohidrat dipengaruhi oleh komponen nutrisi lain dimana semakin tinggi komponen nutrisi lain maka kadar karbohidrat akan semakin rendah dan sebaliknya. Komponen nutrisi lain yang mempengaruhi kandungan karbohidrat diantaranya adalah kandungan protein, lemak, air, abu (Fatkurahman dkk., 2012).

\section{Kadar Serat Kasar}

Serat kasar adalah senyawa yang tidak dapat dicerna dalam organ pencernaan manusia maupun hewan dimana serat ini tidak larut dalam asam $\left(\mathrm{H}_{2} \mathrm{SO}_{4}\right)$ dan basa $(\mathrm{NaOH}) \quad$ (Fatkurahman dkk., 2012). Kandungan serat kasar dalam makanan bisa berguna untuk meringankan sembelit.

Berdasarkan Tabel 2 dapat diketahui substitusi tepung sukun termodifikasi asam asetat menunjukkan kadar serat kasar yang berbeda nyata secara signifikan pada taraf signifikansi $\alpha=0,05$. Semakin banyak jumlah substitusi tepung sukun termodifikasi asam asetat menghasilkan kadar serat kasar yang semakin tinggi. Hal ini sesuai dengan penelitian Astuti dkk. (2013) yang menunjukkan semakin tinggi substitusi tepung sukun dalam pembuatan non flaky crackers memberikan pengaruh terhadap kenaikan kadar serat kasar. Dalam penelitian Astuti dkk. (2013) menyebutkan bahwa tepung sukun mengandung serat kasar sebesar 2,49\% sedangkan serat kasar tepung terigu hanya sebesar 0,4\%. Pada tepung sukun yang termodifikasi asam asetat dimungkinkan terjadi peningkatan kadar serat kasar. Hal ini didukung oleh penelitian Gonzalez and Perez (2002) yang menunjukkan peningkatan kadar serat kasar pada pati beras terasetilasi sebesar 18,18\% dari kadar serat kasar pati beras alami.

\section{Aktivitas Antioksidan}

Antioksidan adalah senyawa yang berguna dalam membantu mengatasi kerusakan oksidatif akibat radikal bebas atau senyawa oksigen reaktif. Antioksidan didapatkan dari daun pandan wangi yang ditambahkan pada proses pembuatan crackers. Senyawa bioaktif yang terdapat pada sari daun pandan wangi diantaranya adalah alkaloid, flavonoid dan polifenol.

Berdasarkan Tabel 2 dapat diketahui bahwa substitusi tepung sukun termodifikasi asam asetat sebesar $0-30 \%$ dengan penambahan sari daun pandan wangi menunjukkan aktivitas antioksidan yang tidak berbeda nyata pada taraf signifikansi $\alpha$ $=0,05$. Aktivitas antioksidan pada ekstrak air daun pandan wangi diketahui sebesar $16,91 \%$ (Yan dan Asmah, 2014). Menurut Wulansari dan Chairul (2011), jika persentase aktivitas antioksidan lebih dari 50\% maka aktivitas antioksidan tergolong tinggi, jika berkisar antara $20-50 \%$ maka aktivitas antioksidan tergolong sedang dan jika kurang dari $20 \%$ maka aktivitas antioksidan tergolong rendah. Aktivitas antioksidan crackers substitusi tepung sukun termodifikasi asam asetat 0$30 \%$ dengan penambahan daun pandan wangi memiliki range nilai sebesar 3,27$4,16 \%$ yang tergolong rendah karena persentase kurang dari $20 \%$. Pada tahapan pembuatan crackers terdapat proses pemanggangan pada suhu $160^{\circ} \mathrm{C}$. Komponen antioksidan tidak tahan panas. Proses pemanasan menyebabkan kerusakan senyawa-senyawa yang memiliki aktivitas antioksidan seperti polifenol. Stabilitas fenol akan terganggu dengan adanya panas yang tinggi (Trissanthi dan Susanto, 2016).

\section{Karakteristik Sensoris Crackers}

Analisis sensoris merupakan pengujian menggunakan indra untuk menilai kualitas 
dan keamanan suatu bahan pangan. Uji kesukaan (hedonic test) bertujuan untuk mengidentifikasi tingkat kesukaan dan penerimaan panelis pada suatu produk. Hasil analisis sensoris menggunakan uji kesukaan dapat dilihat pada Tabel 3.

\section{Warna}

Suatu produk pangan yang bergizi, enak dengan tekstur yang baik tidak dapat diterima apabila memiliki warna yang memberi kesan menyimpang dari warna yang seharusnya (Winarno, 2008). Warna mempengaruhi respon dan persepsi panelis (Setyaningsih dkk., 2010).

Berdasarkan Tabel 3 dapat diketahui substitusi tepung sukun termodifikasi asam asetat menunjukkan beda nyata pada taraf signifikansi $\alpha=0,05$. Setelah dilanjutkan uji DMRT diketahui formula crackers dengan substitusi tepung sukun termodifikasi asam asetat sebesar $10 \%$ tidak berbeda nyata dengan kontrol. Sedangkan formula crackers dengan substitusi tepung sukun termodifikasi asam asetat sebesar 20\% dan 30\% berbeda nyata dengan kontrol. Nilai kesukaan panelis pada parameter warna berkisar antara 3,043,96 yang menunjukkan semua formula bernilai netral-disukai oleh panelis.

Penelitian Mutmainah dkk. (2013) menunjukkan derajat putih tepung sukun termodifikasi asam asetat sebesar 70,14\% lebih rendah dibandingkan derajat putih terigu menurut Widaningrum dkk. (2005) sebesar 86,5\%. Substitusi tepung sukun termodifikasi asam asetat yang semakin banyak menurunkan nilai kesukaan panelis terhadap parameter warna karena crackers cenderung berwarna coklat pucat. Analisis sensoris warna pada non-flaky crackers juga menunjukkan penurunan tingkat kesukaan panelis dengan semakin banyaknya penggunaan tepung sukun (Astuti dkk., 2013).

\section{Aroma}

Industri pangan menganggap pengujian terhadap bau atau aroma sangat penting karena dapat memberikan hasil mengenai kesukaan konsumen terhadap produk (Setyaningsih dkk., 2010). Aroma banyak menentukan kelezatan suatu makanan (Winarno, 2008).

Berdasarkan Tabel 3 dapat diketahui substitusi tepung sukun termodifikasi asam asetat menunjukkan beda nyata pada taraf signifikansi $\alpha=0,05$. Setelah dilanjutkan dengan uji DMRT diketahui formula crackers dengan substitusi tepung sukun termodifikasi asam asetat sebesar 10\% dan $20 \%$ tidak berbeda nyata dengan kontrol. Sedangkan formula crackers dengan substitusi tepung sukun termodifikasi asam asetat sebesar $30 \%$ berbeda nyata dengan kontrol. Nilai kesukaan panelis pada parameter aroma berkisar antara 2,60-3,72 yang menunjukkan semua formula bernilai tidak suka-disukai oleh panelis.

Penelitian yang dilakukan Astuti dkk. (2013) menunjukkan penurunan kesukaan pada aroma non-flaky crackers bayam hijau karena aroma khas dari buah sukun. Berdasarkan penelitian Lubis dkk. (2012), tingkat kesukaan panelis terhadap aroma meuseukat juga menurun seiring dengan penambahan tepung sukun.

\section{Rasa}

Rasa merupakan atribut mutu suatu produk yang merupakan faktor penting bagi konsumen dalam memilih produk. Lima rasa dasar yaitu manis, pahit, asin, asam dan umami (Winarno, 2008).

Tabel 3 Karakteristik Sensoris Crackers Substitusi Tepung Sukun Termodifikasi Asam Asetat dengan Penambahan Sari Daun Pandan Wangi

\begin{tabular}{cccccc}
\hline Formula & Warna & Aroma & Rasa & Tekstur & Overall \\
\hline F1 & $3,72^{\mathrm{b}}$ & $3,60^{\mathrm{bc}}$ & $3,92^{\mathrm{c}}$ & $4,24^{\mathrm{c}}$ & $4,04^{\mathrm{b}}$ \\
F2 & $3,96^{\mathrm{b}}$ & $3,72^{\mathrm{c}}$ & $3,20^{\mathrm{b}}$ & $3,32^{\mathrm{b}}$ & $3,72^{\mathrm{b}}$ \\
F3 & $3,04^{\mathrm{a}}$ & $3,32^{\mathrm{b}}$ & $3,00^{\mathrm{ab}}$ & $2,72^{\mathrm{a}}$ & $3,00^{\mathrm{a}}$ \\
F4 & $3,08^{\mathrm{a}}$ & $2,60^{\mathrm{a}}$ & $2,60^{\mathrm{a}}$ & $2,84^{\mathrm{ab}}$ & $2,80^{\mathrm{a}}$ \\
\hline
\end{tabular}

Keterangan:

1. Formula: F1 (0\% tepung sukun termodifikasi), F2 (10\% tepung sukun termodifikasi), F3 (20\% tepung sukun termodifikasi), F4 (30\% tepung sukun termodifikasi).

2. Skala nilai : (1) sangat tidak suka, (2) tidak suka, (3) netral, (4) suka, (5) sangat suka.

Notasi huruf yang berbeda pada kolom yang sama menunjukkan beda nyata pada taraf signifikansi $\alpha=0.05$ 
Berdasarkan Tabel 3 dapat diketahui substitusi tepung sukun termodifikasi asam asetat menunjukkan beda nyata pada taraf signifikansi $\alpha=0,05$. Setelah dilanjutkan uji DMRT diketahui formula crackers dengan substitusi tepung sukun termodifikasi asam asetat sebesar $10 \%$, 20\% dan $30 \%$ berbeda nyata dengan kontrol. Nilai kesukaan panelis pada parameter rasa berkisar antara 2,60 3,92 yang menunjukkan semua formula bernilai tidak suka-disukai oleh panelis.

Menurut penelitian Astuti dkk. (2013), semakin banyak penggunaan tepung sukun menunjukkan penurunan kesukaan panelis pada non-flaky crackers bayam hijau. Hal ini karena rasa pahit yang disebabkan kandungan tanin yang juga terdapat pada daging buah sukun. Penelitian Sitohang dkk. (2013) juga menunjukkan semakin tinggi penggunaan tepung sukun pada cookies maka nilai organoleptik rasa semakin rendah.

\section{Tekstur}

Tekstur bersifat kompleks dan terkait dengan struktur bahan pangan (Setyaningsih dkk., 2010). Kelayakan suatu produk pangan selain dari segi rasa, warna dan aroma dapat ditentukan oleh tekstur produk tersebut. Pada umumnya crackers memiliki tekstur renyah dan bila dipotong penampang potongannya berlapis-lapis (Manoppo, 2012).

Berdasarkan Tabel 3 dapat diketahui substitusi tepung sukun termodifikasi asam asetat menunjukkan beda nyata pada taraf signifikansi $\alpha=0,05$. Setelah dilanjutkan uji DMRT diketahui formula crackers dengan substitusi tepung sukun termodifikasi asam asetat sebesar 10\%, 20\% dan 30\% berbeda nyata dengan kontrol. Nilai kesukaan panelis pada parameter tekstur berkisar antara 2,724,24 yang menunjukkan semua formula bernilai tidak suka-disukai oleh panelis.

Gluten dalam crackers dapat menahan gas $\mathrm{CO}_{2}$ yang dihasilkan oleh yeast ketika fermentasi sehingga semakin banyak gas $\mathrm{CO}_{2}$ yang dapat diperangkap maka ronggarongga udara yang dihasilkan juga semakin banyak sehingga strukturnya semakin renggang dan mudah dipatahkan (Sarofa dkk., 2010). Selain itu, menurut Muchtadi dkk. (2011), tepung terigu mengandung amilosa sebesar 25\% dan amilopektin sebesar $75 \%$ sedangkan menurut (Guntara dan Prisiska, 2013) tepung sukun mengandung amilosa sebesar $27,7 \%$ dan amilopektin sebesar $72,3 \%$. Produk pangan yang berasal dari pati dengan kandungan amilopektin tinggi bersifat ringan, porous, garing dan renyah.

\section{Overall}

Penerimaan konsumen terhadap suatu produk dapat diukur dari cita rasa meliputi warna, bentuk, ukuran, aroma serta rasa. Uji kesukaan pada parameter overall bertujuan untuk mengetahui tingkat kesukaan panelis pada produk secara keseluruhan.

Berdasarkan Tabel 3 dapat diketahui substitusi tepung sukun termodifikasi asam asetat menunjukkan beda nyata pada taraf signifikansi $\alpha=0,05$. Setelah dilanjutkan uji DMRT diketahui formula crackers dengan substitusi tepung sukun termodifikasi asam asetat sebesar $10 \%$ tidak berbeda nyata dengan kontrol. Nilai kesukaan panelis pada parameter overall berkisar antara 2,80-4,04 yang menunjukkan semua formula bernilai tidak suka-sangat suka oleh panelis.

\section{Penentuan Karakteristik Crackers Terpilih}

Dari semua karakteristik, crackers yang terpilih adalah crackers dengan substitusi tepung sukun termodifikasi asam asetat sebesar $10 \%$ karena secara overall memiliki nilai sensoris yang hampir mendekati kontrol. Menurut Setyaningsih dkk. (2011), analisis sensoris pada produk pangan sangat penting meskipun nilai gizinya sangat tinggi dan higienis, apabila rasanya tidak enak maka nilai gizinya tidak dapat dimanfaatkan. Selera konsumen sangat menentukan dalam penilaian dan penerimaan suatu produk. Analisis sensoris merupakan faktor yang penting dalam pengembangan produk dengan meminimalkan resiko dalam pengambilan keputusan. Panelis dapat melakukan identifikasi sifat-sifat sensori produk yang akan membantu untuk mendeskripsikan produk sehingga produk yang dikembangkan sesuai dengan keinginan panelis dan dapat diterima oleh masyarakat umum.

\section{KESIMPULAN}

Berdasarkan hasil penelitian dan pembahasan yang telah disampaikan maka 
dapat diambil kesimpulan bahwa substitusi tepung sukun termodifikasi asam asetat tidak berpengaruh nyata terhadap karakteristik fisik (kekerasan), karakteristik kimia seperti kadar air, kadar abu, kadar protein, kadar karbohidrat dan aktivitas antioksidan crackers tetapi berpengaruh nyata terhadap kadar lemak dan kadar serat kasar dari crackers. Selain itu substitusi tepung sukun termodifikasi asam asetat berpengaruh nyata terhadap parameter warna, aroma, rasa, tekstur dan overall dari crackers. Crackers yang dihasilkan memiliki aktivitas antioksidan yang tergolong rendah sebesar $3,27-4,16 \%$.

\section{DAFTAR PUSTAKA}

AOAC 2002 Official Methods of Analysis of AOAC International 17th (Washington DC: Association of Official Analytical Chemists)

Appiah, F, J. Y. Asibuo and P. Kumah. 2011. Physicochemical and Functional Properties of Bean Flours of Three Cowpea (Vigna unguiculata L. Walp) Varieties in Ghana. African Journal of Food Science 5(2): 100-104.

Astuti T.Y.I., Ekawati P dan Sinung P. 2013. Subtitusi Tepung Sukun dalam Pembuatan Non Flaky Crakers Bayam Hijau. Jurnal Agros. 1-13.

Fatkurahman, R, Windi A dan Basito. 2012. Karakteristik Sensoris dan Sifat Fisikokimia Cookies dengan Subtitusi Bekatul Beras Hitam (Oryza sativa L.) dan Tepung Jagung (Zea mays L.). Jurnal Teknosains Pangan 1(1): 50-57.

Gonzalez, Z and Elevina P. 2002. Effect of Acetylation on Some Properties of Rice Starch. Starch 54: 148-154.

Guntara, M dan Fajar P. 2013. Pengaruh Pati Sukun (Artocarpus altilis (Park.) Fosberg.) Terpregelatinisasi Fosfat sebagai Matriks terhadap Disolusi Tablet Lepas Lambat Teofilin. Farmasains 2(1): 5-10.

Hartanti, F.D, Bambang S.A dan Dimas R.A.M. 2013. Kajian Karakteristik Fisikokimia Tepung Sukun (Artocarpus communis) Termodifikasi dengan Variasi Lama Perendaman dan
Konsentrasi Asam Laktat. Jurnal Teknosains Pangan 2(4).

Manoppo, S. 2012. Studi Pembuatan Crackers dengan Sukun (Artocarpus comunis) Pragelatinisasi. Skripsi Program Studi Ilmu dan Teknologi Pangan, Jurusan Teknologi Pertanian, Universitas Hasanuddin, Makasar.

Marina, R dan Endang P.A. 2012. Potensi Daun Pandan (Pandanus amaryllifolius) dan Mangkokan (Notophanax scutellarium) sebagai Repelen Nyamuk Aedes albopictus. Aspirator 4(2): 85-91.

Muchtadi, T.R, Sugiyono dan Fitriyono A. 2011. Ilmu Pengetahuan Bahan Pangan. Alfabeta. Bandung.

Mutmainah, F, Dimas R dan Bambang S.A. 2013. Kajian Karakteristik Fisikokimia Tepung Sukun (Artocarpus communis) Termodifikasi dengan Variasi Lama Perendaman dan Konsentrasi Asam Asetat. Jurnal Teknosains Pangan 2(4).

Purba, S. B. 2002. Karakterisasi Tepung Sukun (Artcarpus altilis) Hasil Pengering Drum dan Aplikasinya untuk Substitusi Tepung Terigu pada Pembuatan Biskuit. Skripsi, Jurusan Teknlogi Pangan dan Gizi, Fakultas Teknologi Pertanian, Institut Pertanian Bogor, Bogor.

Sabirin, M. Budi K, Bambang T., Yanuar S. P dan Andy M. P. 2012. Modifikasi Tepung Sorgum untuk Substitusi Tepung Gandum sebagai Bahan Baku Industri Pangan Olahan (Noodle dan Cookies). Laporan Hasil Penelitian dan Pengembangan, Kekayaan Intelektual, dan Hasil Pengelolaannya. Insentif PKPP No. Urut : 49.

Sarofa, U, Ratna Y dan Mardiyah. 2010. Pemanfaatan Tepung Buah Lindur (Bruguiera gymnorrhiza) dalam Pembuatan Crackers dengan Penambahan Gluten. Program Studi Teknologi Pangan, Fakultas Teknologi Industri, UPN "Veteran" Jawa Timur.

Setyaningsih, D, Anton A dan Maya P.S. 2010. Analisis Sensori untuk Industri Pangan dan Agro. IPB Press. Bogor.

Sitohang, K.A.K, Zulkifli L dan Linda M.L. 2015. Pengaruh Perbandingan Jumlah 
Tepung Terigu dan Tepung Sukun dengan Jenis Penstabil terhadap Mutu Cookies Sukun. Jurnal Rekayasa Pangan dan Pertanian 3(3): 308-315.

Sudarmadji, S, Bambang $\mathrm{H}$ dan Suhardi. 1989. Analisa Bahan Makanan dan Pertanian. Liberty. Yogyakarta.

Sugito dan Ari H. 2006. Penambahan Daging Ikan Gabus (Ophicepallus strianus BLKR) dan Aplikasi Pembekuan pada Pembuatan Pempek Gluten. Jurnal Ilmu-Ilmu Pertanian 8(2): 147-151.

Sugiyono, Esther M dan Aton Y. 2013. Pembuatan Crackers Jagung dan Pendugaan Umur Simpannya dengan Pendekatan Air Kritis. Jurnal Teknologi dan Industri Pangan 24(2): 129-137.

Trissanthi, C. M dan Wahono H. S. 2016. Pengaruh Konsentrasi Asam Sitrat dan Lama Pemanasan terhadap Karakteristik Kimia dan Organoleptik Sirup Alang-Alang (Imperata cylindrica). Jurnal Pangan dan Industri 4(1):180-189.

Waryat, M.Y dan Yossi H. 2014. Diversifikasi Pangan dari Tepung Sukun untuk Mengurangi Konsumsi Tepung Terigu di Kepulauan Seribu, Provinsi DKI Jakarta. Buletin Pertanian Perkotaan 4(1): 13-19.

Widaningrum, Sri W, dan Soewarno T.S. 2005. Pengayaan Tepung Kedelai pada Pembuatan Mie Basah dengan Bahan Baku Tepung Terigu yang Disubstitusi Tepung Garut. Jurnal Pascapanen 2(1): 41-48.

Winarno, F. G. 2008. Kimia Pangan dan Gizi. Gramedia. Jakarta.

Winata, A. Y. 2001. Karakterisasi Tepung Sukun (Artocarpus atilis) Pramasak Hasil Pengeringan Drum serta Aplikasinya untuk Substitusi Tepung Terigu pada Pembuatan Roti Manis. Skripsi, Fakultas Teknologi Pertanian, Institut Pertanian Bogor, Bogor.

Wulansari, D dan Chairul. 2011. Penapisan Aktivitas Antioksidan dan Beberapa Tumbuhan Obat Indonesia Menggunakan Radikal 2,2-Diphenyl-1
Picrylhydrazyl (DPPH). Majalah Obat Tradisional 16(1): 21-25.

Yan S, W dan Asmah R. 2010. Comparison of Total Phenolic Contents and Antioxidant Activities of Turmeric Leaf, Pandan Leaf and Torch Ginger Flower. International Food Research Journal 17: 417-423. 